\title{
Cell-derived anaphylatoxins as key mediators of antibody-dependent type II autoimmunity in mice
}

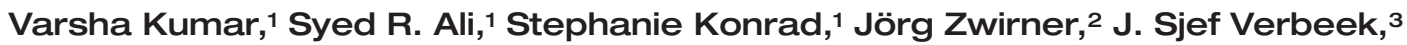 \\ Reinhold E. Schmidt, ${ }^{1}$ and J. Engelbert Gessner ${ }^{1}$
}

\begin{abstract}
${ }^{1}$ Department of Clinical Immunology, Medical School Hannover, Hannover, Germany. ${ }^{2}$ Department of Immunology, Georg August University Göttingen, Göttingen, Germany. ${ }^{3}$ Department of Human Genetics, Leiden University Medical Centre, Leiden, The Netherlands.
\end{abstract}

\begin{abstract}
Complement C5a, a potent anaphylatoxin, is a candidate target molecule for the treatment of inflammatory diseases, such as myocardial ischemia/reperfusion injury, RA, and the antiphospholipid syndrome. In contrast, up until now, no specific contribution of $\mathrm{C5a}$ and its receptor, $\mathrm{C5aR}$, was recognized in diseases of antibody-dependent type II autoimmunity. Here we identify C5a as a novel key mediator of autoimmune hemolytic anemia (AIHA) and show that mice lacking C5aR are partially resistant to this IgG autoantibody-induced disease model. Upon administration of anti-erythrocyte antibodies, upregulation of activating Fc $\gamma$ receptors ( Fc $\gamma \mathrm{Rs}$ ) on Kupffer cells, as observed in WT mice, was absent in C5aR-deficient mice, and Fc $\gamma$ R-mediated in vivo erythrophagocytosis was impaired. Surprisingly, in mice deficient in Fc $\gamma$ RI and Fc $\gamma$ RIII, anti-erythrocyte antibody-induced $\mathrm{C} 5$ and $\mathrm{C} 5 \mathrm{a}$ production was abolished, demonstrating the existence of a previously unidentified $\mathrm{Fc} \gamma \mathrm{R}$-mediated C5a-generating pathway. These results show that the development of a full-blown antibody-dependent autoimmune disease requires $C 5 \mathrm{a}$ - produced by and acting on $\mathrm{Fc} \gamma \mathrm{R}$ - and may suggest therapeutic benefits of $\mathrm{C} 5$ and/or C5a/C5aR blockade in AIHA and other diseases closely related to type II autoimmune injury.
\end{abstract}

\section{Introduction}

C5a anaphylatoxin, the smaller proteolytic fragment of complement component 5 , induces several biological responses at very low concentrations and is involved in inflammatory and anaphylactic reactions (1). Its receptor, $\mathrm{C} 5 \mathrm{aR}$, has been identified on a variety of immune effector cells, including circulating leukocytes, mast cells, basophils, macrophages, and many others (2). Activation of these cells by $\mathrm{C} 5 \mathrm{a}$ results in inflammatory mediator release and granule secretion, which in turn alters vascular permeability, induces smooth muscle contraction, and promotes inflammatory cell migration $(1,2)$. It is well established that this C5a-triggered cascade of events contributes to the pathogenesis of various diseases in humans, including myocardial ischemia/ reperfusion injury and respiratory distress syndrome (3-5). In addition, genetic deletion of $\mathrm{C} 5 \mathrm{aR}$ is very effective in preventing inflammation in animal models of erosive arthritis and the neutrophil-dependent antiphospholipid syndrome $(6,7)$. So far, however, no specific role for $\mathrm{C} 5 \mathrm{a}$ is recognized in diseases of antibody-dependent type II autoimmunity.

In the present study we investigated the pathological significance of $\mathrm{C} 5 \mathrm{a}$ and $\mathrm{C} 5 \mathrm{aR}$ in the development of autoimmune hemolytic anemia (AIHA) in mice. The data suggest a previously unidentified function of C5a for autoantibody-induced cellular destruction through cross-talk of $\mathrm{C} 5 \mathrm{aR}$ with activating $\mathrm{F} c \gamma$ receptors ( $\mathrm{F} c \gamma \mathrm{Rs}$ ) specifically on liver macrophages but not sinusoidal endothelial

Nonstandard abbreviations used: AIHA, autoimmune hemolytic anemia; C5aR, C5a anaphylatoxin receptor; FcR, Fc receptor; Fc $\gamma$ R, Fc receptor; FcR $\gamma$ chain, common $\gamma$ chain of FcR; Ht, hematocrit; MACS, magnetic activated cell sorting; PM, peritoneal macrophage; PMN, polymorphonuclear leukocyte; PNH, paroxysmal nocturnal hemoglobinuria; SEC, sinusoidal endothelial cell.

Conflict of interest: The authors have declared that no conflict of interest exists. Citation for this article: J. Clin. Invest. 116:512-520 (2006). doi:10.1172/JCI25536. cells (SECs). Moreover, the data also provide the first evidence, to our knowledge, of a specific requirement of Kupffer cell $\mathrm{F} c \gamma \mathrm{R}$ for C5 and C5a production in anemia. Thus, 2 distinct levels of interactions exist between $\mathrm{Fc} \gamma \mathrm{R}$ and $\mathrm{C} 5 \mathrm{a} / \mathrm{C} 5 \mathrm{aR}$, indicating that $\mathrm{C} 5 \mathrm{a}$ anaphylatoxins may represent a relevant therapeutic target in the treatment of type II autoimmune injury.

\section{Results}

Protection against lethality in AIHA in both FcyRI/III- and C5aR-deficient mice. In a number of autoimmune diseases, autoantibodies are the essential pathogenic factors, e.g., anti-rbc antibodies in AIHA (8). The pathogenicity of the autoantibody can be attributed mainly to the effector functions associated with its $\mathrm{Fc}$ region, e.g., interactions with $\mathrm{Fc}$ receptor $(\mathrm{FcR})$ and the complement system $(9,10)$. This has been studied extensively in New Zealand black (NZB) mice, which spontaneously develop anemia as a result of production of autoreactive Coombs anti-rbc antibodies (11). Several cytotoxic antibodies have been derived from NZB mice, and most of them induce anemia by extravascular hemolysis in i.p. injected animals (12). Passive immunization with IgG2b and IgG3 autoantibodies results in a preferential activation of the complement system, leading to complement receptor-3-dependent erythrophagocytosis (13), whereas the pathogenic effects of an anti-rbc IgG1 105-2H antibody are mediated exclusively by FcyRIII on the splenic macrophages and hepatic Kupffer cells (14).

The IgG2a 34-3C autoantibody directed against the anion channel band 3 on erythrocytes $(11,15)$ is by far the most pathogenic, and a single i.p. injection of $300 \mu \mathrm{g}$ of the antibody is sufficient to induce lethal AIHA in WT mice. In contrast, NOD mice, which carry mutations at multiple complement and $\mathrm{F} c \gamma \mathrm{R}$ gene loci (16, 17), were resistant (Figure 1A), as were mice deficient either in the common $\gamma$ chain of FcRs (FcR $\gamma$ chain) or in both Fc $\gamma R I$ and Fc $\gamma R$ III 

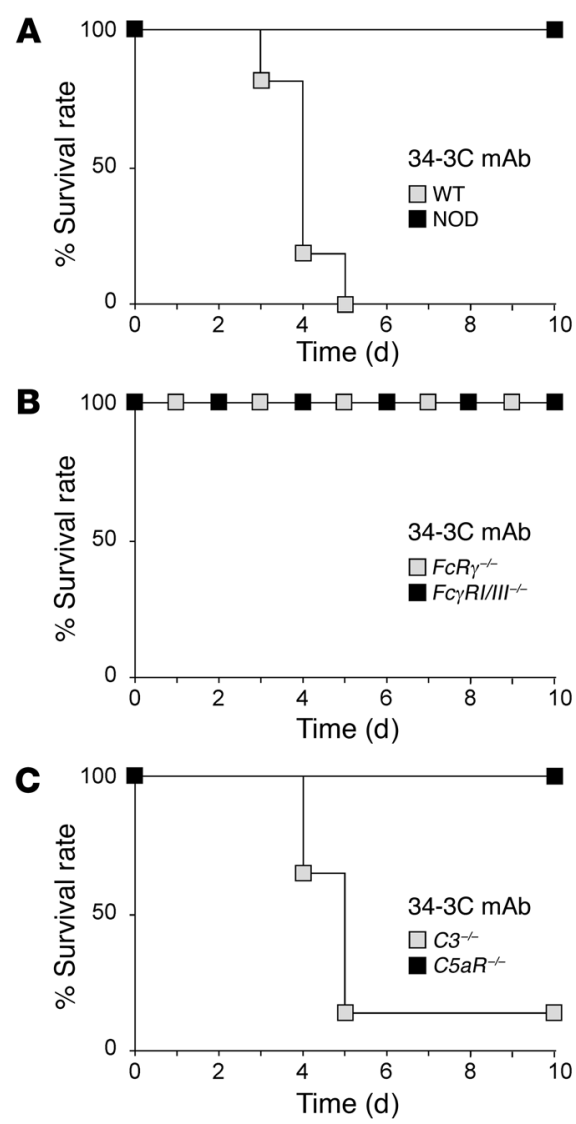

(Figure 1B). These results are in agreement with data of the sublethal AIHA models $(14,18)$, confirming that the activating FcyRI and Fc $\gamma$ RIII are essential for the induction of AIHA. Despite the strong complement-fixing activity of the 34-3C autoantibody, passively induced antibody-dependent AIHA was only affected in part in $\mathrm{C}^{-1-}$ mice (Figure 1C); this supported the previous conclusion that complement $\mathrm{C} 3$ does play a role but not the dominant one in $34-3 \mathrm{C}$ autoimmunity (13). However, unexpectedly, we found that $\mathrm{C} 5 \mathrm{aR} \mathrm{R}^{-/-}$mice were resistant to $300 \mu \mathrm{g}$ i.p. injected 34-3C IgG2a mAb (Figure 1C), indicating that 34-3C-induced lethal hemolytic anemia depends not only on Fc $\gamma \mathrm{R}$ but also on C5aR.

Reduced 34-3C mAb-induced cytotoxic response in FcR-and C5aR-deficient mice. Given the protective

\section{Figure 2}

Reduced cytotoxic response in both FcR- and C5aRdeficient mice during 34-3C mAb-induced AlHA. Daily $\mathrm{Ht}$ levels of WT C57BL/6 (open circles), FcR $\gamma^{-1-}$ (filled circles), $F C \gamma R I / I I I^{--}$(filled squares), and $C 5 a R^{-/-}$(filled triangles) mice injected with increasing dosages of $25 \mu \mathrm{g}$ (A), $75 \mu \mathrm{g}(\mathbf{B}), 150 \mu \mathrm{g}(\mathbf{C})$, and $300 \mu \mathrm{g}$ (D) of anti-rbc $34-3 \mathrm{C}$ mAb. Ht values lower than $40 \%$ were considered anemic. Death of a mouse is indicated by a cross. Results are shown as the mean $\mathrm{Ht} \pm \mathrm{SD}$ obtained from 4-9 mice in each group. Significant differences were determined by Student's $t$ test $\left({ }^{*} P<0.05 ;{ }^{* *} P<0.001\right)$.

\section{Figure 1}

Lethal 34-3C mAb-induced AlHA is Fc $\gamma \mathrm{RI} / \mathrm{III}-$ and C5aR-depen-

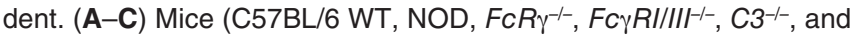
$\mathrm{C} \mathrm{a} R^{-1-}$ ) received $300 \mu \mathrm{g}$ of anti-rbc $34-3 \mathrm{C}$ mAb i.p., and lethality was recorded at the indicated times. Results are expressed as percentage survival rate for groups of 10-24 mice. No lethality developed in mice receiving the isotype-matched $\mathrm{W} 6 / 32 \mathrm{mAb}$ (data not shown).

phenotype of C5aR deficiency in lethal AIHA, we next determined the cytotoxic response induced by lower doses of the 34-3C autoantibody in $\mathrm{C} 5 \mathrm{aR} \mathrm{R}^{-/-}$mice as compared with $\mathrm{FcR} \gamma^{-/-}$and $\mathrm{Fc \gamma RI} / \mathrm{III}^{-/-}$ mice. Anemia occurring in C57BL/6 WT mice injected with 25, 75 , and $150 \mu \mathrm{g}$ 34-3C IgG2a mAb (hematocrit [Ht]: $36.0 \% \pm 0.9 \%$, $27.0 \% \pm 0.8 \%$, and $17.8 \% \pm 1.2 \%$, respectively, at day $3 ; n=5$ ) was equally prevented or strongly reduced in FcR- and C5aR-deficient mice, with mean $\mathrm{Ht}$ levels remaining at $40 \%$ or greater (25 and $75 \mu \mathrm{g})(P<0.001)$ or having a minor decrease to $31-32 \%(150 \mu \mathrm{g})$ $(P<0.001)$ (Figure 2, A-C). While the $F c R \gamma^{-1-}, F c \gamma R I / I I I^{-/-}$, and $\mathrm{C} 5 \mathrm{a} \mathrm{R}^{-1-}$ mice each showed protection against lethality in AIHA induced by $300 \mu \mathrm{g}$ 34-3C mAb, a persistent though diminished anemia was observed in all the knockouts (Figure 2D). These results suggest that activating $\mathrm{Fc} \gamma \mathrm{R}$ and $\mathrm{C} 5 \mathrm{aR}$ act on the same pathway in 34-3C autoimmunity and indicate that, under conditions of high 34-3C mAb titers, additional factors, such as the activation of C3 (13), also play a contributory role.

Reduced Kupffer cell-mediated destruction of autoantibody-opsonized rbcs in mice lacking either activating $F c \gamma R$ or the $C 5 a R$. FcyR-dependent erythrophagocytosis, especially by liver Kupffer cells, had previously been shown to be a major cause of the 34-3C mAb-induced anemic phenotype in mice $(10,12,14,19)$. Because C5aR- and FcR-deficient mice both display an identical pattern of protection/ reduction with respect to lethality and Ht levels (Figures 1 and 2), we examined the relevance of $\mathrm{C} 5 \mathrm{aR}$ and $\mathrm{Fc} \gamma \mathrm{R}$ to in vivo erythrophagocytosis. The 34-3C mAb-induced cytotoxic response was followed in kinetic studies by quantitative assessment of the percent-
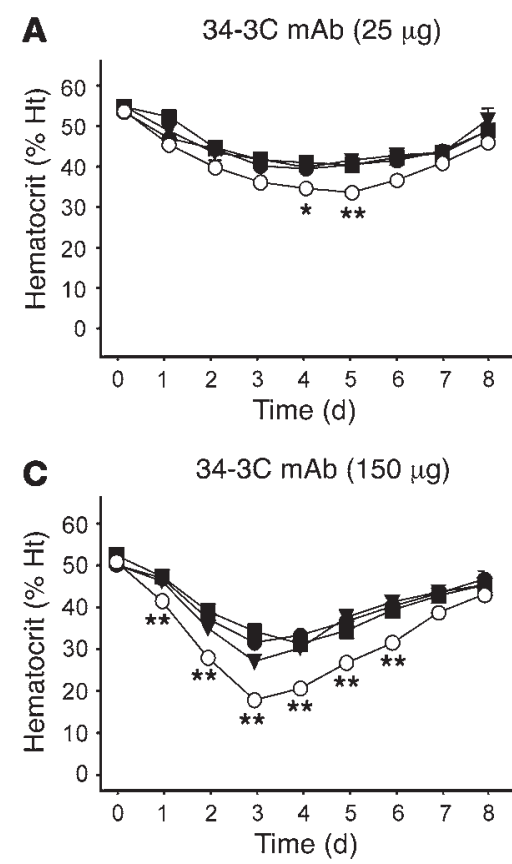
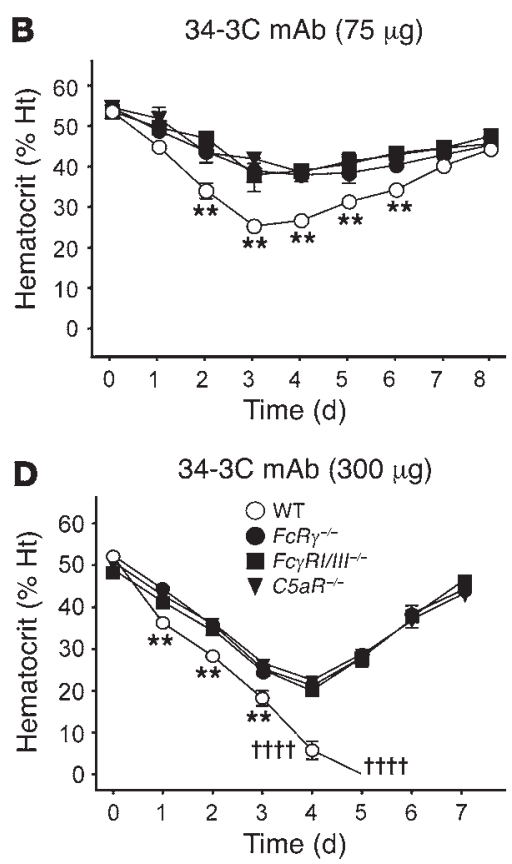


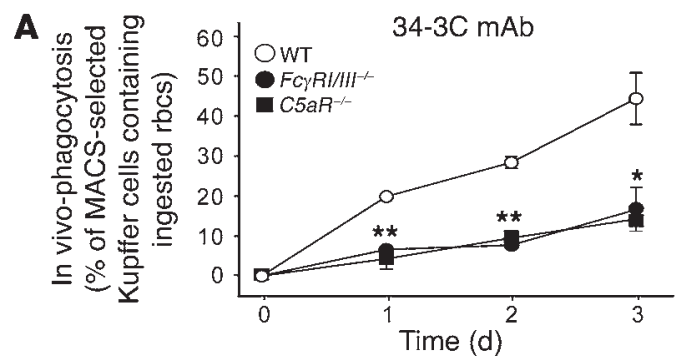

B

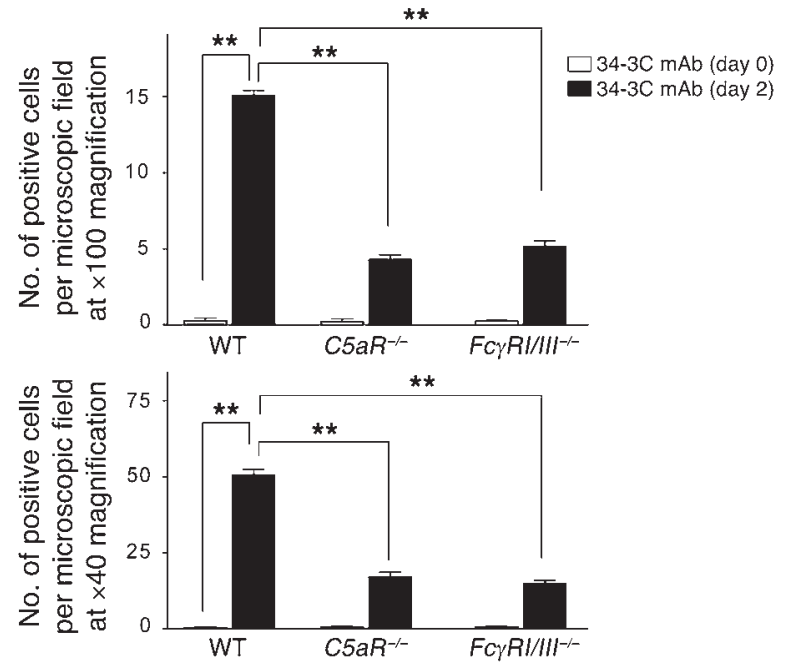

age of Mac-1-positive liver Kupffer cells that contained ingested erythrocytes. As shown in Figure 3, WT C57BL/6 mice displayed an excessive Kupffer cell-mediated clearance of rbcs within 3 days after 34-3C mAb treatment. C5aR $\mathrm{R}^{-/-}$and $\mathrm{Fc} \gamma \mathrm{RI} / \mathrm{III} \mathrm{I}^{-/-}$mice equally exhibited diminished pathology with only minor hepatic erythrophagocytosis (Figure 3A). These findings were confirmed by qualitative (see Supplemental Figure 1; available online with this article; doi:10.1172/JCI25536DS1) and quantitative (Figure 3B) histological studies on liver sections. The cell count of WT phagocytic liver cells per microscopic field (original magnifications, $\times 40$ and $\times 100$ ) was markedly reduced in both $\mathrm{C} 5 \mathrm{aR}-$ and $\mathrm{Fc} \gamma \mathrm{R}$-deficient mice $(P<0.001$; Figure 3B)

Coexpression of C $5 a R$ and $F c \gamma R$ on Kupffer cells. The liver consists mainly of hepatocytes, SECs, and Kupffer cells. In 2 independent studies $(20,21)$, it was previously shown that the anti-Fc $\gamma$ RII/III $\mathrm{mAb} 2.4 \mathrm{G} 2$ interacts with both SECs (Mac-1-negative cells) and macrophages (Mac-1-positive Kupffer cells). C5aR expression on these 2 different FcR-positive liver cell populations was analyzed using rat anti-mouse C5aR mAb 1/36 (22) in flow cytometry of subsets of liver cells, which were isolated by the collagenase perfusion method, separated from hepatocytes by density centrifugation, and selected for the presence or absence of Mac-1

\section{Figure 4}

Coexpression of $\mathrm{C} 5 \mathrm{aR}$ and $\mathrm{F} \gamma \gamma \mathrm{R}$ on Mac-1-positive liver Kupffer cells. Liver nonparenchymal cells were separated into Mac-1-positive Kupffer cells (KC) and Mac-1-negative SECs by magnetic activated cell sorting (MACS). All cell fractions were stained with PE-anti-Fc $\gamma$ RII/ RIII 2.4G2 mAb in combination with FITC-conjugated anti-F4/80 or anti-C5aR 1/36 mAbs and analyzed on a FACScan. Representative results of individual mice are shown.

\section{Figure 3}

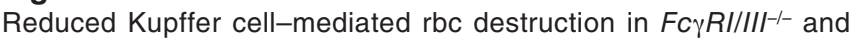
C5aR ${ }^{-1-}$ mice during 34-3C mAb-induced AlHA. (A) WT C57BL/6 (open

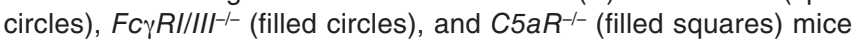
injected with $300 \mu \mathrm{g}$ of anti-rbc 34-3C mAb were analyzed for Kupffer cell-mediated in vivo phagocytosis at the indicated times. Results are shown as the percentage of Mac-1-selected Kupffer cells containing more than 2 ingested rbcs \pm SD obtained from 4-9 mice in each group. (B) H\&E-stained liver sections obtained from the indicated mice at days 0 and 2 after AlHA induction were analyzed for erythrophagocytosis by light microscopy. Shown is the mean cell count \pm SEM of rbc-containing liver cells per microscopic field (original magnifications, $\times 40$ and $\times 100$ ) obtained from 3-5 mice in each group. ( $\mathbf{A}$ and $\mathbf{B}$ ) Significant differences were determined by Student's $t$ test $\left({ }^{\star} P<0.05\right.$; $\left.{ }^{\star} P<0.001\right)$.

expression by magnetic cell sorting. Mac-1-positive Kupffer cells showed a positive staining with both $1 / 36$ and $2.4 \mathrm{G} 2$, while Mac-1-negative SECs stained only with 2.4G2 (Figure 4). So, Kupffer cells, but not SECs, express Fc $\gamma \mathrm{R}$ as well as C5aR on their surface.

C5aR-dependent upregulation of Kupffer cell Fc $\gamma R I / I I I$ expression in $A I H A$. It has been shown recently that, in different in vivo mouse models of antibody-dependent inflammatory diseases, C5a positively regulates expression of FcyR (23-26). Also, Kupffer cells isolated from anemic WT mice displayed strongly increased lev-

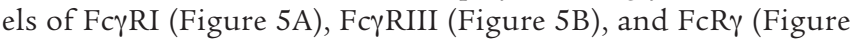
5C) mRNA at 24 hours after 34-3C mAb injection. This activation of the transcription of the Fc $\gamma R$ genes was completely absent in $\mathrm{C} \mathrm{aR}^{-/-}$mice (Figure 5), demonstrating that also in AIHA C5a/C5aR mediates upregulation of activating Fc $\gamma$ R.

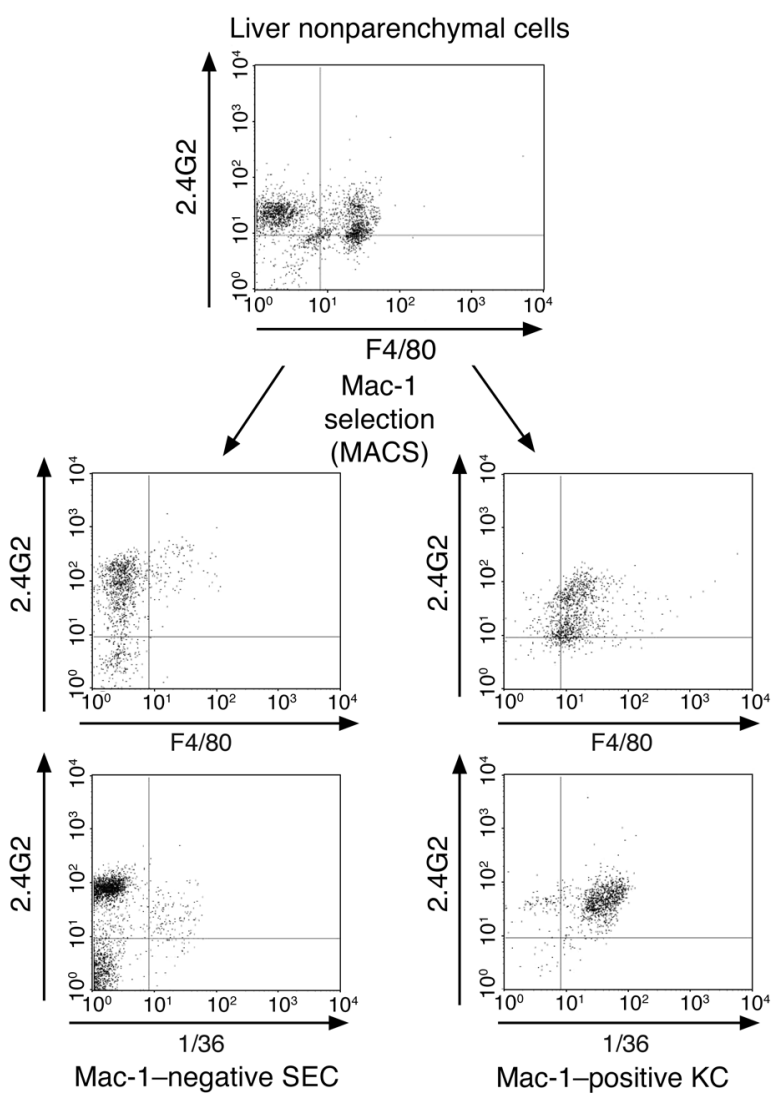



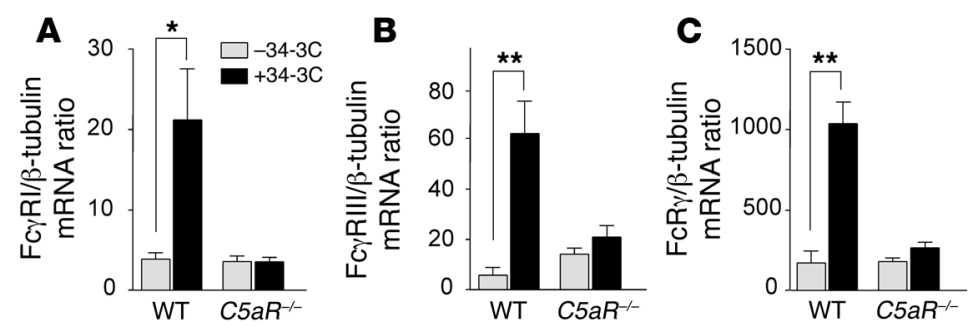

Figure 5

C5aR-dependent upregulation of FcyRI/RIII mRNA in Kupffer cells during AlHA. mRNA expression of $\mathrm{Fc} \gamma \mathrm{RI}(\mathbf{A}), \mathrm{Fc} \gamma \mathrm{RIII}(\mathbf{B})$, and $\mathrm{FcR} \gamma(\mathbf{C})$ was determined by TaqMan RT-PCR analysis of liver Kupffer cells derived from C57BL/6 WT and $\mathrm{C} \mathrm{a} \mathrm{R}^{-/-}$mice at 24 hours after injection of $34-3 \mathrm{C} \mathrm{mAb}$ (black bars) as compared with mice not receiving 34-3C mAb (gray bars). Results are expressed as mean values \pm SD obtained from 3-5 mice in each group. Significant differences were determined by Student's $t$ test $\left({ }^{*} P<0.05\right.$; $\left.{ }^{* *} P<0.001\right)$.

Fc $\gamma$ R-dependent C5 and C5a production in AIHA. Bioactive C5a in homogenate supernatants from liver samples taken at various time points after 34-3C-induced AIHA was determined by measurement of C5a-mediated C5aR-triggered neutrophil chemotactic activity in a Transwell chemotaxis chamber. In WT and $\mathrm{C}^{\mathrm{a}} \mathrm{R}^{-/-}$mice, C5a was produced in liver early during the onset of anemia, reaching maximal levels at 6 hours with a sustained plateau between 24 and 72 hours (Figure 6, A and B). In marked contrast, $F c \gamma R I / I I I^{-/-}$ mice showed strongly diminished levels (by more than $90 \%$; $P<0.001$ as compared with WT C57BL/6 mice) of C5a in the liver 24 hours after AIHA (Figure 6B). Moreover, in FcR-positive liver cells of all WT mice analyzed, mRNA expression of C5 was markedly upregulated in Kupffer cells but not SECs after 4 hours of 34-3C treatment (Figure 6C). This 34-3C-induced activation of C5 mRNA synthesis, which also occurred in $\mathrm{C}^{\mathrm{a}} \mathrm{a} \mathrm{R}^{-/-}$mice, was completely abrogated in $F c \gamma R I / I I I^{-/-}$mice (Figure 6D), suggesting that, in antibody-dependent hemolytic anemia, engagement of activating Fc $\gamma \mathrm{R}$ by 34-3C-opsonized erythrocytes strongly triggers C5 and $\mathrm{C} 5 \mathrm{a}$ production.
Generation of C5a by ex vivo-stimulated Kupffer cells but not SECs. Because Kupffer cells showed an FcyR-dependent increase of C5 mRNA in AIHA, we speculated that activation of these effector cells may be directly involved in the generation of C5a. To test this hypothesis, we analyzed the C5a production in primary cultures of both Kupffer cells and SECs. In line with the data on C5 mRNA regulation in anemia, 3-hour incubation with 34-3C IgG2a-opsonized rbcs ( $20 \mu \mathrm{g}$ of the $\mathrm{mAb}$ was used for opsonization) was associated with an induction of bioactive C5a in culture supernatants of Kupffer cells (Figure 7A) but not SECs (Figure 7B). C5a production mediated by 34-3C was not observed in controls when non-opsonized rbcs were used (Figure 7, A and B).

Effects of C5 and C5aR inbibition and Fc $\mathrm{R}$ R/III deficiency on C5a production and phagocytosis by macrophages in vitro. To extend the results from the in vivo and ex vivo studies, we also conducted both in vitro phagocytosis and C5a production experiments using peritoneal macrophages (PMs) from healthy WT C57BL/6 mice. First, series of various doses (0, 5, 10, 20 , and $30 \mu \mathrm{g}$ ) of the $34-3 \mathrm{C} \mathrm{mAb}$ were used for IgG opsonization of rbcs. There was a significant increase in phagocytic activity with increasing dosage and a concomitant increase of bioactive C5a in the culture supernatant of PMs (Figure 8, A and B). A concentration of $20 \mu \mathrm{g}$ 34-3C mAb was then used for opsonization in all subsequent experiments. In contrast with PMs from WT mice, FcyRI/III-negative PMs failed to produce C5a upon stimulation, and, as expected, in vitro phagocytosis was markedly decreased (Figure 8, C and D). When PMs were preincubated with the neutralizing anti-C5aR mAb 1/36 (22), the capacity of these cells to phagocytose $34-3 \mathrm{C}$-bound rbcs was also substantially reduced (Figure 8E). Similar results were obtained after treatment with an anti-C5 mAb (Figure 8E). PMs treated with anti-C5 mAbs, but not those treated with anti-C5aR mAbs, showed strongly diminished C5a production (Figure $8 \mathrm{~F}$ ), confirming the reported specificity of the anti-C5 mAb BB5.1 in blocking the cleavage site of C5 (27). Collectively, these data demonstrate that engagement of activat-

\section{Figure 6}

FcyR-dependent C5a production and induction of C5 mRNA synthesis in Kupffer cells but not SECs in anemia. (A and B) Supernatants of liver homogenates from WT mice collected at different time points $(\mathbf{A})$ or from WT, C5aR ${ }^{-/-}$, and $F_{C \gamma} R I / I I I^{---}$mice collected 24 hours after AlHA induction (B) were assayed for C5a-dependent chemotactic activity on PMNs derived from WT mice (black bars) or $\mathrm{C} \mathrm{aR} \mathrm{R}^{-/-}$mice (negative control, gray bars). (C and D) Kupffer cell and SEC C5 mRNA levels

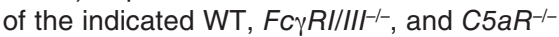
mice at 4 hours after injection of 34-3C mAb (black bars) as compared with mice not receiving $34-3 \mathrm{C}$ mAb (gray bars). (A-D) Results are expressed as mean values \pm SD obtained from 3-5 mice in each group. Significant differences were determined by Student's $t$ test $\left({ }^{* *} P<0.001\right)$.
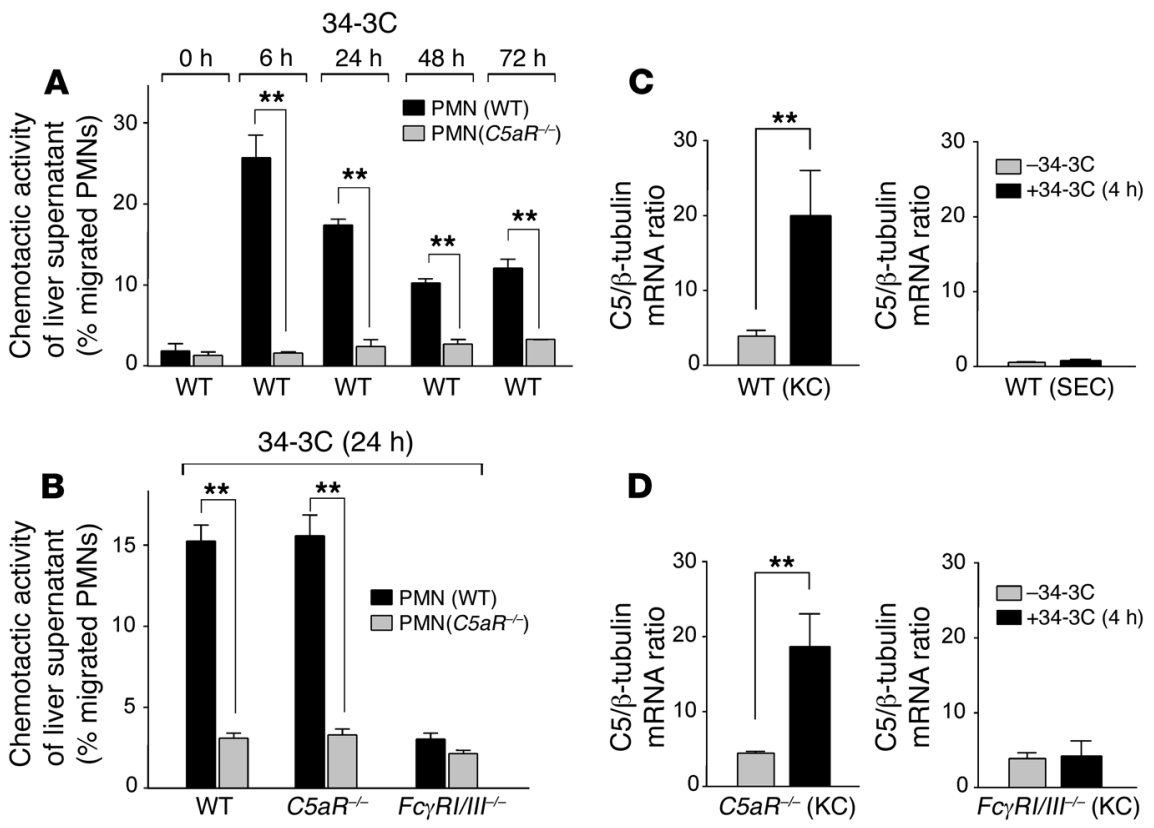
A

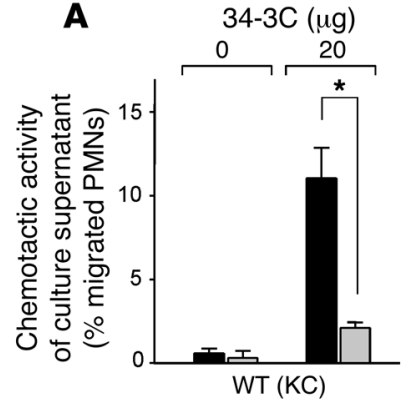

B

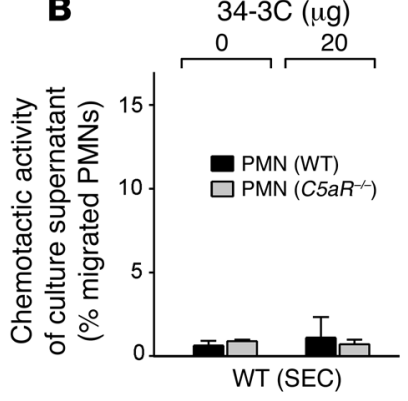

Figure 7

34-3C mAb-induced C5a production in primary cultures of Kupffer cells but not SECs. Cultured Kupffer cells (A) and SECs (B) from WT mice were incubated with rbcs opsonized with 34-3C mAb $(20 \mu \mathrm{g})$ or with rbcs alone $(0 \mu \mathrm{g})$. After 3 hours of incubation, culture supernatants were assayed for $\mathrm{C} 5 \mathrm{a}$-dependent chemotactic activity on PMNs derived from WT mice (black bars) or $\mathrm{C} \mathrm{a} \mathrm{R}^{-1-}$ mice (gray bars). (A and $\mathbf{B}$ ) Results are expressed as mean values \pm SD obtained from 2 individual experiments performed in duplicate. Significant differences were determined by Student's $t$ test $\left({ }^{\star} P<0.05\right)$. ing Fc $\gamma$ R on 2 different macrophage populations, the Kupffer cells (Figures 6 and 7) and PMs (Figure 8), can trigger the production of C5 and C5a that is integral for FcyR-mediated erythrophagocytosis both in vitro and in vivo.

Effect of inhibitory Fc $\gamma$ RII deficiency on phagocytosis and C5/C5a production in vitro and during anemia in vivo. In $\mathrm{Fc}_{\mathrm{R}} \mathrm{HI}^{-/-}$mice (28), immune inflammation critically depends on the balance of activating $\mathrm{Fc} \gamma \mathrm{R}$ and inhibitory Fc $\gamma$ RII signals $(29,30)$, and amelioration of the type II autoimmune response in immune thrombocytopenic purpura by intravenous Igs correlates with high expression levels of Fc $\gamma$ RII (31). Given the critical importance of both C5aR and Fc $\gamma$ R in anemia, we thus finally evaluated the role of FC $\mathrm{RII}$ in C5a production, phagocytosis, and 34-3C type II autoimmunity. Fc $\gamma \mathrm{RII}^{-/-}$ PMs, when compared with WT PMs, exhibited a significantly enhanced phagocytosis (Figure 9A) and C5a production (Figure 9B), indicating that Fc $\gamma \mathrm{RII}$ can negatively regulate $\mathrm{F} c \gamma \mathrm{RI}$ - and $\mathrm{F} c \gamma$ RIII-triggered activation of PMs. However, the genetic deletion of FcyRII had no substantial influence on the 34-3C-induced anemic phenotype for all parameters analyzed, including $\mathrm{C} 5$ gene induction on Kupffer cells (Figure 10A), liver C5a production (Figure 10B), and the timeand dose-dependent clearance of rbcs when measured for both Ht levels and the percentage of Mac-1-selected Kupffer cells containing

\section{Figure 8}

Fc $\gamma$ R-dependent $\mathrm{C} 5$ a production and $\mathrm{C} 5 / \mathrm{C} 5 \mathrm{a} /$ C5aR-dependent phagocytosis of 34-3C IgGopsonized rbcs in peritoneal macrophages (PMs) in vitro. (A-F) Adherent PM cells from WT or Fc $\gamma R I / I I^{-1-}$ mice were incubated with rbcs opsonized with the indicated doses of the 34-3C mAb in the absence or presence of the 2 blocking antiC5 $(\alpha \mathrm{C} 5)$ or anti-C5aR $(\alpha \mathrm{C} 5 \mathrm{aR}) \mathrm{mAbs}$. (A, C, and $\mathbf{E})$ After 4 hours of incubation, extracellular rbcs were lysed by a hypotonic shock, and the percentage of PM cells that had ingested more than $1 \mathrm{rbc}$ was determined by light microscopy as described in Methods. (B, D, and F) After 3 hours of incubation at $37^{\circ} \mathrm{C}$, culture supernatants were assayed for $\mathrm{C} 5 \mathrm{a}$-dependent chemotactic activity on PMNs derived from WT mice (black bars) or $\mathrm{C}^{2} \mathrm{aR} \mathrm{R}^{-/-}$mice (gray bars). (A-F) Results are expressed as the mean values \pm SD from $2-3$ individual experiments performed in duplicate. Significant differences were determined by Student's $t$ test $\left({ }^{\star} P<0.05 ;{ }^{\star \star} P<0.001\right)$.
A
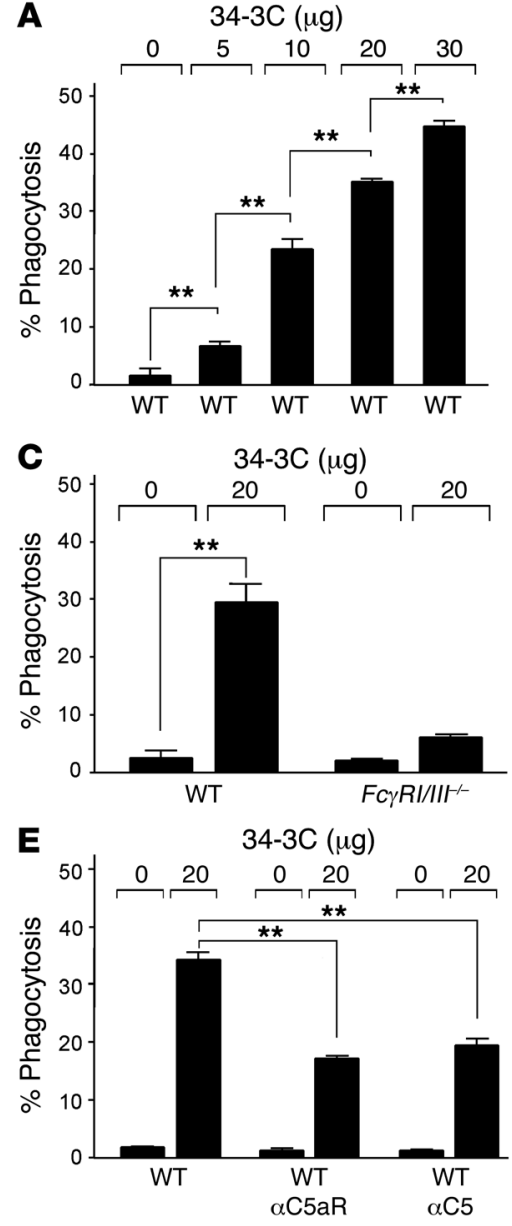

B

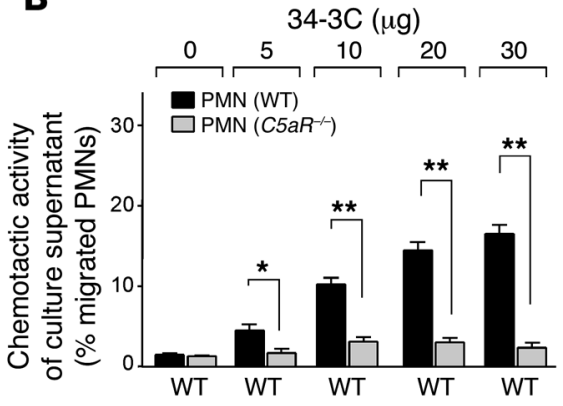

D

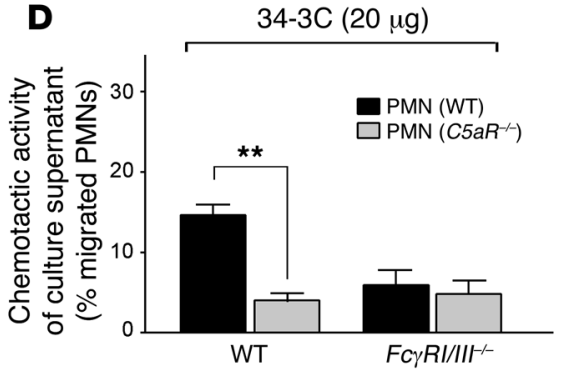

$\mathbf{F}$

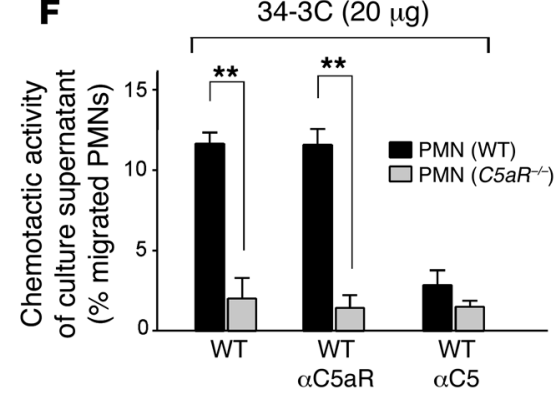



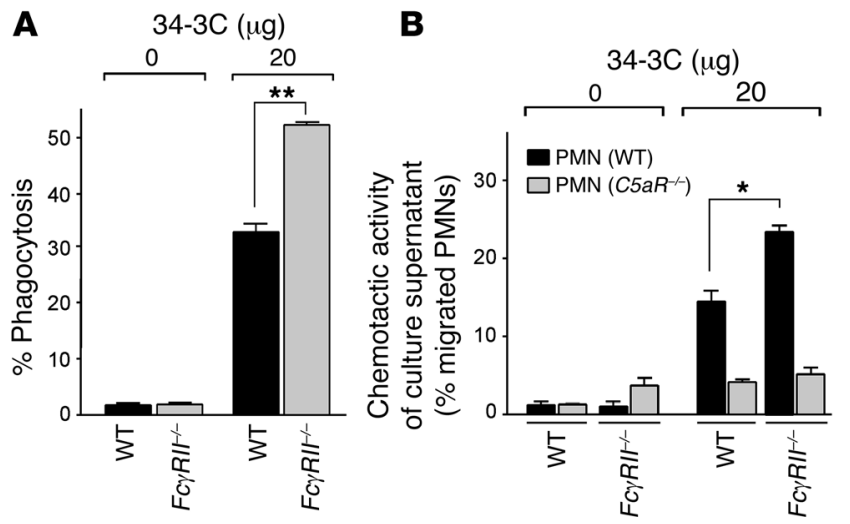

antibody-mediated type II autoimmunity, which was not expected before. Studies with macrophage-depleted mice demonstrated that Kupffer cells are one of the crucial effector cell types in murine AIHA (32). Our results clearly show that in vivo phagocytosis of 34-3C-opsonized erythrocytes by Kupffer cells is strongly impaired in $\mathrm{C}_{5} \mathrm{aR} \mathrm{R}^{-/-}$mice, indicating that this process requires $\mathrm{C} 5 \mathrm{aR}$, which, along with activating $\mathrm{Fc} \gamma \mathrm{R}$, is expressed on liver Kupffer cells. Recently, it was reported that C5a positively regulates $F c \gamma R$ in IgG-mediated lung inflammation and peritonitis (23-26). These data, combined with our observations that the release of C5a was rapidly induced in hemolytic anemia and $\mathrm{C} 5 \mathrm{aR}$ was required for 34-3C-induced increase of Fc $\gamma \mathrm{RI}$ and Fc $\gamma \mathrm{RIII}$ expression in Kupffer cells, indicate that $\mathrm{C} 5 \mathrm{a}$ acts as a general regulator of $\mathrm{Fc} \gamma \mathrm{R}$ expression at different tissue sites in both antibody-dependent inflammation and autoimmune disease.

In addition, our results concerning the source of $\mathrm{C} 5 \mathrm{a}$ production in vitro and in vivo unexpectedly revealed that $\mathrm{Fc} \gamma \mathrm{Rs}$ on Kupffer cells are critically required for $\mathrm{C} 5$ a production. $\mathrm{Fc} \gamma \mathrm{RI} / \mathrm{III}^{-/-}$mice enabled us to identify the activating $\mathrm{Fc} \gamma \mathrm{Rs}$ as dominant mediators of autoantibody-induced release of C5a in AIHA. Since Fc $\gamma \mathrm{RI} / \mathrm{III}^{-/-}$ mice are resistant to lethal hemolytic anemia, the classical and alternative pathways of complement activation appear insufficient to compensate for the lack of cellular Fc $\gamma \mathrm{R}$ in the Kupffer cellmediated induction of the release of C5a by the liver. Moreover,

\section{Figure 9}

Enhanced phagocytosis and C5a production in PMs from FcyRll-defi-

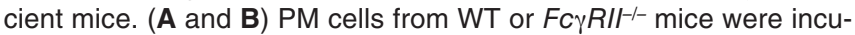
bated with rbcs opsonized with $34-3 \mathrm{C}$ mAb $(20 \mu \mathrm{g})$ or with rbcs alone $(0 \mu \mathrm{g})$. Quantitative assessment of phagocytosis (A) and C5a production (B) was performed as described in the legend to Figure 8. Results are expressed as mean \pm SEM from 2 individual experiments performed in triplicate (A) or duplicate (B). Significant differences were determined by Student's $t$ test $\left({ }^{\star} P<0.05 ;{ }^{* \star} P<0.001\right)$.

cell culture experiments demonstrate these cells to be fully competent for serum complement-independent $\mathrm{C} 5$ and $\mathrm{C} 5 \mathrm{a}$ production that, as further documented in PMs, requires the presence of Fc $\gamma$ R. Our data are thus consistent with a pathogenic mechanism of antibody-dependent hemolytic anemia in which IgG-opsonized erythrocytes, perhaps through a C5 cleavage enzyme from Kupffer cells, trigger Fc $\gamma$ R-mediated C5 synthesis and C5a release, which in turn activate a positive cellular feedback signal upon engagement of C5aR, resulting in increased Fc $\gamma \mathrm{RI}$ and $\mathrm{Fc} \gamma \mathrm{RIII}$ expression required for effective erythrophagocytosis. These results not only show the relevance of threshold activation of $\mathrm{Fc} \gamma \mathrm{R}$ regulated by $\mathrm{C} 5 \mathrm{a}$ activity in AIHA but also underscore the importance of $\mathrm{Fc} \gamma \mathrm{Rs}$ as cellular mediators of a novel discrete C5a-generating pathway. Exploiting this regulatory loop of C5a and Fc $\gamma \mathrm{R}$ offers new insights into the cellular mechanisms that determine the pathogenic effects of autoantibodies.

Currently, it is thought that immune inflammation and antibody-induced autoimmunity are regulated by the balance of acti-

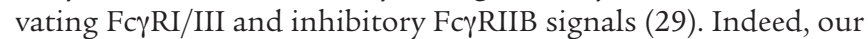
results in cell culture systems show that autoantibody-induced generation of $\mathrm{C} 5 \mathrm{a}$ and in vitro phagocytosis of 34-3C-opsonized erythrocytes are negatively influenced by Fc $\gamma$ RII in PMs. However, $F c \gamma R I I^{-1-}$ mice exhibit no enhanced Kupffer cell-dependent C5 synthesis and cellular clearance. High Fc $\gamma$ RII levels are detectable in both PM cells and liver SECs but are limited in Kupffer cells. This may explain why the condition of Fc $\gamma$ RII deficiency results in a normal, not enhanced, autoantibody-triggered anemic phenotype and may also indicate that Fc $\gamma$ RII, while considered a potential therapeutic target in other autoimmune diseases (33), is not a likely candidate target molecule for the treatment of anemia.

\section{Figure 10}

34-3C mAb-induced AIHA is FcyRll-independent. (A-D) Experimental AlHA was induced in WT or $F C \gamma R I I^{-/-}$mice by i.p. injection of $300 \mu \mathrm{g}(\mathbf{A}, \mathbf{B}$, and $\mathbf{D})$ or the indicated doses (C) of the pathogenic 34-3C mAb, and the mice were examined at 4 hours for C5 mRNA levels in Kupffer cells (A), at 24 hours for C5a production in liver supernatants (B), at 96 hours for $\mathrm{Ht}$ levels (C), and at day 1-3 for in vivo erythrophagocytosis by Mac-1-selected Kupffer cells (D). Results are expressed either as mean values \pm SD obtained from 3-6 mice in each group (A and $\mathbf{B})$ or as values of individual mice (C and $\mathbf{D})$. No significant differences were observed between WT and $\mathrm{FC}_{\mathrm{C} R \mathrm{RI}^{--}}$mice for all parameters.
A

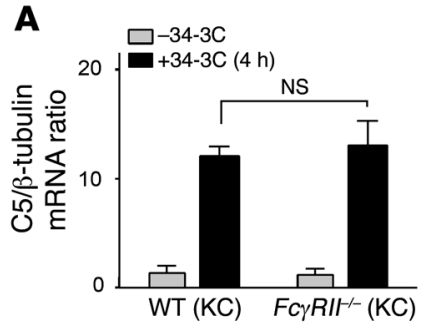

B

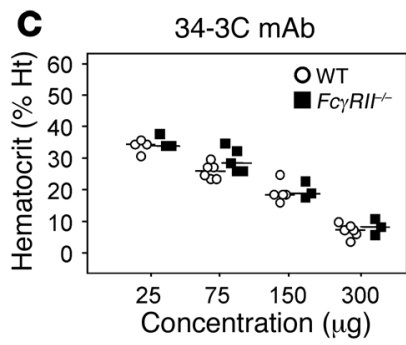

D
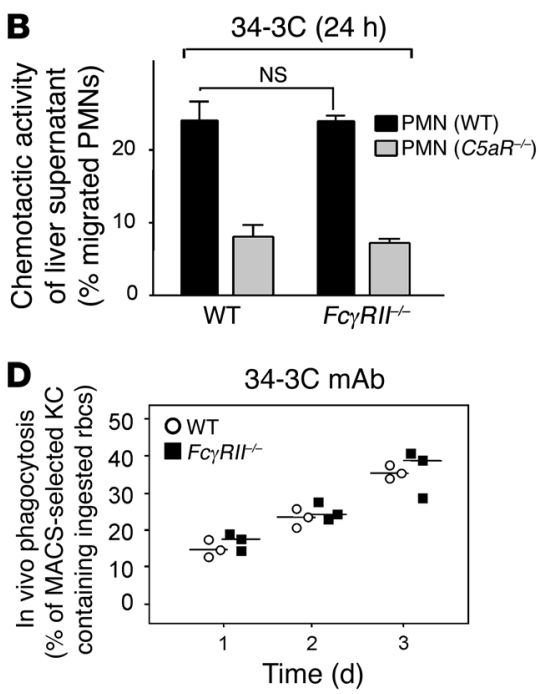

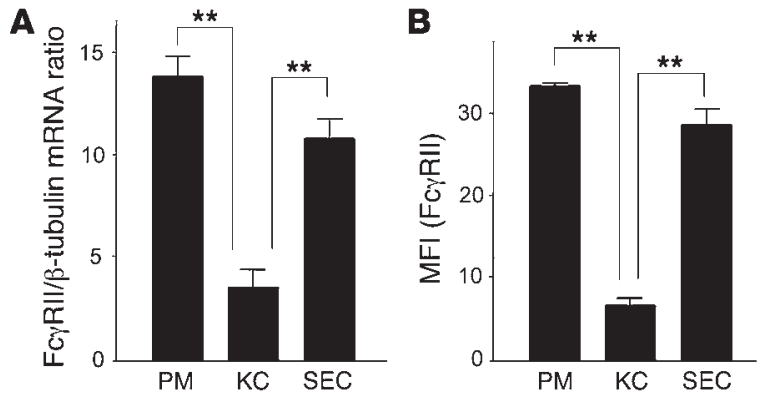

Figure 11

Expression analysis of FcyRII in Kupffer cells and SECs as compared with PM cells. ( $\mathbf{A}$ and $\mathbf{B}$ ) The indicated cells were MACS-isolated from the peritoneum and liver of C57BL/6 WT mice and analyzed for production of Fc $\gamma$ RII mRNA (A) by real-time RT-PCR and Fc $\gamma$ RII protein (B) by flow cytometry using the anti-FcyRII Ly17.2 mAb conjugated to FITC. Results are expressed as mean \pm SEM from 3-4 mice. Significant differences were determined by Student's $t$ test $\left({ }^{* *} P<0.001\right)$. $\mathrm{MFI}$, mean fluorescence intensity.

Our work significantly extends previous reports that describe a dominant contribution of activating $\mathrm{Fc} \gamma$ receptors in experimental models of type II autoimmune diseases $(23,29,33)$. The results presented here provide evidence that $\mathrm{C} 5 \mathrm{a}$, which is produced by and acts on $\mathrm{F} c \gamma \mathrm{R}$, can serve as a critical sensor of autoantibodymediated effects in AIHA. We also note that inhibition of C5 and inhibition of $\mathrm{C} 5 \mathrm{aR}$ are each effective in reducing Fc-mediated phagocytosis, indicating an important role of C5a rather than $\mathrm{C} 5 \mathrm{~b}$ in the lysis of sensitized rbcs in vitro. The physiological relevance of this finding has yet to be determined in vivo. It may well be that C5b-induced formation of the membrane attack complex accounts for the residual anemia at high autoantibody titers in $\mathrm{C} 5 \mathrm{aR}$ deficiency. The identification of the requirement of cellderived C5 and C5a for immune elimination of erythrocytes by $\mathrm{Fc} \gamma \mathrm{R}$ defines a novel mechanism of cell lysis in anemia and may suggest the potential use of anaphylatoxins as therapeutic targets for the control of AIHA. Anti-C5 biologicals, such as eculizumab (34), have already shown beneficial effects of C5 inhibition to reduce hemolysis in patients with paroxysmal nocturnal hemoglobinuria (PNH) (35). However, clinical studies in which AIHA has been treated in similar ways are not realized. Despite the fact that the molecular events of rbc destruction are quite different in AIHA and PNH (a disease that arises via somatic gene mutations and subsequent production of blood cells with a deficiency of surface proteins that protect the cells against attack by the complement system), our findings in mice may support the view that blockade of C5 cleavage into C5a and C5b would be a reasonable approach for the treatment of not only PNH but also other hematological disorders, as suggested here for AIHA.

\section{Methods}

Mice. The generation of $\mathrm{Fc}_{\mathrm{C}} \mathrm{RI}^{-/-}$and $\mathrm{Fc}_{\mathrm{C}} \mathrm{RIII}^{-/-}$mice derived from ES cells of 129 origin and backcrossed for more than 4 generations with C57BL/ 6 mice has been described previously $(18,36)$. These mice were then intercrossed to obtain mice doubly deficient in Fc $\gamma \mathrm{RI}$ and Fc $\gamma \mathrm{RIII}$. The homozygous FcyRI/III $I^{-/-}$mice were selected, and $\mathrm{Fc} \gamma \mathrm{RI} / \mathrm{III}^{+/+}$WT C57BL 6 littermates were used for all comparisons. $\mathrm{F}_{c} \gamma \mathrm{RII}^{-/-}, \mathrm{C} \mathrm{aR} \mathrm{R}^{-/-}$, and $\mathrm{C} 3^{-/-} \mathrm{C} 57 \mathrm{BL} / 6$ mice were kindly provided by T. Takai (Tohoku University, Sendai, Japan) (28), U. Höpken (Max-Delbrück-Center for Molecular Medicine, Berlin,
Germany) (37), and M. Carroll (Harvard University, Boston, Massachusetts, USA) (38). $F c R \gamma^{-/}$C57BL/6 mice were purchased from Taconic. NOD mice were obtained from Charles River Laboratories. All these mice were used at 8-14 weeks of age. Experiments were performed with approval from the Bezirksregierung Hannover.

Experimental AIHA. Mouse anti-mouse rbc IgG2 monoclonal autoantibody 34-3C (a non-agglutinating $\mathrm{mAb}$ ) (12) was purified from tissue culture supernatant by protein $\mathrm{G}$ affinity chromatography. Mice were injected i.p. with different dosages of 25-300 $\mu \mathrm{g}$ of 34-3C or the same amounts of isotype-matched control antibody W6/32 (14). Survival was monitored, and daily Ht levels were determined with heparinized microhematocrit capillary tubes in a microfuge ( 5 minutes at $13,900 \mathrm{~g}$ ) using blood samples obtained from the retroorbital plexus. H\&E-stained formalin-fixed sections of major organs were prepared from mice sacrificed at days 0 and 2 after 34-3C injection and examined for histopathological changes. Livers obtained after perfusion were processed for examinations of C5a bioactivity, erythrophagocytosis, and both Kupffer cell and SEC F $\gamma \gamma R, C 5$, and C5aR mRNA/protein. Perfused liver was excised, minced into small pieces, and treated with HBSS plus $0.025 \%$ collagenase V (Sigma-Aldrich); this was followed by passages through stainless steel gauze (mesh, 500 and $100 \mu \mathrm{m}$ ) to obtain single-cell suspensions. Parenchymal hepatocytes were discarded by sedimentation at $50 \mathrm{~g}$. The remaining nonparenchymal cell fraction was centrifuged at $800 \mathrm{~g}$ for 10 minutes and immediately taken for SEC and Kupffer cell isolation and analysis as described below, while the obtained supernatant was stored at $-80^{\circ} \mathrm{C}$ for later determination of C5a bioactivity.

SEC and Kupffer cell isolation. The resuspended nonparenchymal cells were layered on Percoll gradient (50\% and 25\%; density, $1.07 \mathrm{~g} / \mathrm{ml}$ and $1.03 \mathrm{~g} / \mathrm{ml}$, respectively) and centrifuged at $1,000 \mathrm{~g}$ for 20 minutes. The interphase containing mainly SECs and Kupffer cells was again centrifuged and resuspended in $80 \mu \mathrm{l}$ of modified PBS buffer containing $0.5 \%$ BSA plus 0.2 mM EDTA. Twenty microliters of Mac-1 magnetic beads (Miltenyi Biotec) were added and incubated for 15 minutes, followed by 2 washes and a final resuspension in $2 \mathrm{ml}$ of modified PBS buffer prior to magnetic activated cell sorting (MACS). AutoMACS separation of Kupffer cells was done using the Posseld program for a double selection of Mac-1-positive cells to attain maximum purity ( $>97 \%$, as assessed by flow cytometry using FITC-F4/80 mAb staining). Both the obtained Mac-1-positive Kupffer cells and the Mac-1-negative SECs were used for comparative analysis.

Determination of erythrophagocytosis by Kupffer cells. Mac-1-selected Kupffer cells were isolated from mice sacrificed 1-3 days after 34-3C injection as described before and examined for erythrophagocytosis by light microscopy. Cells containing more than 2 rbcs were considered phagocytic. A total of 200 Kupffer cells were counted by 2 blinded reviewers in 4-6 C57BL/6, $\mathrm{C} 5 \mathrm{aR} \mathrm{R}^{-/}$, and $\mathrm{Fc \gamma} \mathrm{RI} / \mathrm{III} \mathrm{I}^{-/}$mice, and the percentage of Mac-1-positive cells showing ingested rbcs was determined for each group of mice.

$C 5, C 5 a R$, and Fc $\gamma$ R expression and transcription analysis. Expression of C5aR and Fc $\gamma$ R on liver cells $\left(2 \times 10^{4}\right)$ before and after MACS separation was measured by flow cytometry, using a FACScan flow cytometer (BD). The following FITC- and PE-conjugated antibodies were used: anti-FcrRII (Ly17.2) (20); anti-FcyRII/III (clone 2.4G2) and anti-Mac-1 (clone M1/70.15) (both from BD Biosciences - Pharmingen); anti-F4/80 (Serotec); and anti-C5aR (clone 1/36) (22). In some experiments, total RNA was prepared from both SEC and Kupffer cell preparations of both anemic and nonanemic mice using RNAzol reagent (WAK-Chemie Medical GmbH) and analyzed for Fc $\gamma R I, F c \gamma$ RII, Fc $\gamma$ RIII, FcR $\gamma$, and C5aR transcription levels normalized to tubulin by both TaqMan (Applied Biosystems) and real-time RT-PCR using published primers and probes $(24,26,39)$. For detection of C5 transcripts, the following C5-specific primers were used: sense, 5'-GCATTTCTGACACCAGGCTTC-3'; antisense, 5'-AGCGCACAGTCAGCTTCCA-3' (40). 
Determination of C5a bioactivity. Liver supernatants collected from mice sacrificed 1-3 days after 34-3C injection were used for the determination of autoantibody-induced C5a-mediated neutrophil chemotactic activity in anemia. In addition, culture supernatants of SECs, Kupffer cells, and PM cells obtained in vitro at 3 hours after incubation with 34-3C-opsonized rbcs were also used. Bone marrow cells (consisting of $64-68 \%$ neutrophils) from C57BL 6 and $\mathrm{C} 5 \mathrm{aR} \mathrm{R}^{-/-}$mice were suspended at $7.5 \times 10^{6} \mathrm{cells}$ per milliliter RPMI 1640 medium and 0.5\% BSA. One hundred microliters of the bone marrow cell suspension was placed into the insert of a Transwell chemotaxis chamber, and the bottom well was filled with $600 \mu \mathrm{l}$ of liver and culture supernatants diluted 1:2 in RPMI/1\% BSA. Inserts were combined to the lower chambers and incubated at $37^{\circ} \mathrm{C}$ and $6 \% \mathrm{CO}_{2}$ for 2 hours. After the incubation, $50 \mu \mathrm{l}$ of $70 \mathrm{mM}$ EDTA solution was added into the lower chambers to release adherent cells from the lower surface of the membrane and from the bottom of the well. Plates were further incubated 30 minutes at $4^{\circ} \mathrm{C}$, inserts were removed, and the transmigrated neutrophils were vigorously suspended and counted with a FACSCalibur (BD Biosciences) for 1 minute at $60 \mu \mathrm{l} / \mathrm{min}$ with gating on forward and side scatter. Migration of polymorphonuclear leukocytes (PMNs) from the insert to the bottom well was quantitated as percentage of total PMNs loaded into the upper chamber.

34-3C mAb activation of PMs in vitro. Resident PM cells were flushed out of the peritoneal cavity of WT, Fc $\mathrm{RI} / \mathrm{III}^{-/-}$, or $\mathrm{Fc}_{\mathrm{C}} \mathrm{RII}^{-/-}$mice, washed twice with PBS, and suspended in RPMI 1640 medium and 1\% BSA. The PM cells were allowed to adhere for 4 hours on chamber slides (Nunc) at a density of $3 \times 10^{5}$ cells per well, followed by the removal of nonadherent cells and overnight incubation. Freshly isolated rbcs from WT mice were washed twice with ice-cold PBS by centrifugation at $550 \mathrm{~g}$ and processed for opsonization. Hereby, $10 \mu \mathrm{l}$ of pelleted rbcs were incubated at $4^{\circ} \mathrm{C}$ for 1 hour with $10 \mu \mathrm{l}$ of $34-3 \mathrm{C} \mathrm{mAb}$ at subsaturating to saturating concentrations $(5-30 \mu \mathrm{g} / \mathrm{ml})$. Aliquots of $200 \mu \mathrm{l}$ of $1 \%$ opsonized rbc suspension were added to each well and incubated at $37^{\circ} \mathrm{C}$ for 3 or 4 hours. For some experiments, PM cells were first incubated for 1 hour at $37^{\circ} \mathrm{C}$ with the blocking 1/36 anti-C5aR (22) and BB5.1 anti-C5 (27) (provided by Roche) antibodies. Culture supernatants were collected after 3 hours of incubation and analyzed for bioactive $\mathrm{C} 5 \mathrm{a}$ as described before. After 4 hours of incubation, noningested extracellular rbcs were lysed by hypotonic shock, immediately followed by 2 washes with PBS. PM cells were fixed with $4 \%$ paraformaldehyde and conventionally stained with Giemsa/H\&E, and phagocytosis was determined by light microscopy.

Statistics. Statistical analysis was performed using the Prism 4 statistical software package (GraphPad Software). To analyze differences in mean values, a 2 -tailed unpaired Student's $t$ test was used. $P<0.05$ was considered statistically significant, and $P<0.001$ was considered highly significant.

\section{Acknowledgments}

We thank O. Felda, A. Mishra, C. Klein, K. Jagavelu, and A. Gossler for their technical support. V. Kumar received a fellowship from the GK705 graduate program of the Deutsche Forschungsgemeinschaft (DFG). S.R. Ali received a fellowship from the international $\mathrm{MD} / \mathrm{PhD}$ program of the Medical School Hannover. The research was supported, in part, by a grant from the DFG to J.E. Gessner (Ge892/8-1).

Received for publication May 3, 2005, and accepted in revised form November 15, 2005.

Address correspondence to: Johannes Engelbert Gessner, Abteilung für Klinische Immunologie, Medizinische Hochschule Hannover, Carl-Neuberg-Strasse 1, 30625 Hannover, Germany. Phone: 49-511-532-3621; Fax: 49-511-532-5648; E-mail: gessner.johannes@mh-hannover.de.
1. Ember, J.A., Jagels, M.A., and Hugli, T.E. 1998. Characterization of complement anaphylatoxins and their biological responses. In The human com plement system in health and disease. J.E. Volankis and M.M. Frank, editors. Marcel Dekker Inc. New York, New York, USA. 241-284.

2. Gerard, C., and Gerard, N.P. 1994. C5a anaphylatoxin and its seven transmembrane-segment receptor. Annu. Rev. Immunol. 12:775-808.

3. Vakeva, A.P., Agah, A., Rollins, S.A., Matis, L.A., and Stahl, G.L. 1998. Myocardial infarction and apoptosis after myocardial ischemia and reperfusion: role of the terminal complement components and inhibition by anti-C5 therapy. Circulation. 97:2259-2267.

4. Fitch, J.C., et al. 1999. Pharmacology and biological efficacy of a recombinant, humanized, single-chain antibody C5 complement inhibitor in patients undergoing coronary artery bypass graft surgery with cardiopulmonary bypass. Circulation. 100:2499-2506.

5. Stevens, J.H., et al. 1986. Effects of anti-C5a antibodies on the adult respiratory distress syndrome in septic primates. J. Clin. Invest. 77:1812-1816.

6. Ji, H., et al. 2002. Arthritis critically dependent on innate immune system players. Immunity. 16:157-168.

7. Girardi, G., et al. 2003. Complement C5a receptors and neutrophils mediate fetal injury in the antiphospholipid syndrome. J. Clin. Invest. 112:1644-1654. doi:10.1172/JCI200318817.

8. Gehrs, B.C., and Friedberg, R.C. 2002. Autoimmune hemolytic anemia. Am. J. Hematol. 69:258-271.

9. Schreiber, A.D., and Frank, M.M. 1972. Role of antibody and complement in the immune clearance and destruction of erythrocytes. I. In vivo effects of IgG and IgM complement-fixing sites. J. Clin. Invest. 51:575-582.
10. Clynes, R., and Ravetch, J.V. 1995. Cytotoxic antibodies trigger inflammation through $\mathrm{Fc}$ receptors. Immunity. 3:21-26.

11. Izui, S. 1994. Autoimmune hemolytic anemia. Curr. Opin. Immunol. 6:926-930.

12. Shibata, T., et al. 1990. Monoclonal anti-erythrocyte autoantibodies derived from NZB mice cause autoimmune hemolytic anemia by two distinct pathogenic mechanisms. Int. Immunol. 2:1133-1141.

13. Azaredo da Silveira, S., et al. 2003. Complement activation selectively potentiates the pathogenicity of the IgG2b and IgG3 isotypes of a high affinity antierythrocyte autoantibody. J. Exp. Med. 195:665-672.

14. Meyer, D., et al. 1998. FcrRIII (CD16)-deficient mice show IgG isotype-dependent protection to experimental autoimmune hemolytic anemia. Blood. 92:3997-4002.

15. Leddy, J.P., Falany, J.L., Kissel, G.E., Passador, S.T., and Rosenfeld, S.I. 1993. Erythrocyte membrane proteins reactive with human (warm-reacting) antired cell autoantibodies. J. Clin. Invest. 91:1672-1680.

16. Prins, J.B., et al. 1993. Linkage on chromosome 3 of autoimmune diabetes and defective $\mathrm{Fc}$ receptor for IgG in NOD mice. Science. 260:695-698.

17. Johansson, A.C., et al. 2001. Genetic control of collagen-induced arthritis in a cross with NOD and $\mathrm{C} 57 \mathrm{BL} / 10$ mice is dependent on gene regions encoding complement factor 5 and FcgammaRIIb and is not associated with loci controlling diabetes. Eur. J. Immunol. 31:1847-1856.

18. Ioan-Facsinay, A., et al. 2002. Fc $\gamma$ RI (CD64) contributes substantially to severity of arthritis, hypersensitivity responses, and protection from bacterial infection. Immunity. 16:391-402.

19. Fossati-Jimack, L., et al. 2000. Markedly different pathogenicity of four immunoglobulin $\mathrm{G}$ isotypeswitch variants of an antierythrocyte autoantibody is based on their capacity to interact in vivo with the low-affinity Fcgamma receptor III. J. Exp. Med. 191:1293-1302.

20. Schiller, C., et al. 2000. Mouse Fc $\gamma$ RII is a negative regulator of Fc $\gamma$ RIII in IgG immune complex-triggered inflammation but not in autoantibodyinduced hemolysis. Eur. J. Immunol. 30:481-490.

21. Ahmed, S.S., et al. 1995. Fc receptors in liver sinusoidal endothelial cells in NZB/W F1 lupus mice: a histological analysis using soluble immunoglobulin G-immune complexes and a monoclonal antibody (2.4G2). Hepatology. 22:316-324.

22. Soruri, A., Kim, S., Kiafard, Z., and Zwirner, J. 2003. Characterization of C5aR expression on murine myeloid and lymphoid cells by the use of a novel monoclonal antibody. Immunol. Lett. 88:47-52.

23. Schmidt, R.E., and Gessner, J.E. 2005. Fc receptors and their interaction with complement in autoimmunity. Immunol. Lett. 100:56-67.

24. Shushakova, N., et al. 2002. C5a anaphylatoxin is a major regulator of activating versus inhibitory Fc $\gamma$ Rs in immune complex-induced lung disease. J. Clin. Invest. 110:1823-1830. doi:10.1172/ JCI200318817.

25. Godau, J., et al. 2004. C5a initiates the inflammatory cascade in immune complex peritonitis. J. Immunol. 173:3437-3445.

26. Skokowa, J., et al. 2005. Macrophages induce the inflammatory response in the pulmonary Arthus reaction through $\mathrm{G \alpha}_{\mathrm{i} 2}$ activation that controls $\mathrm{C} 5 \mathrm{aR}$ and $\mathrm{Fc}$ receptor cooperation. J. Immunol. 174:3041-3050.

27. Frei, Y., Lambris, J.D., and Stockinger, B. 1987. Generation of a monoclonal antibody to mouse C5 application in an ELISA assay for detection of anti-C5 antibodies. Mol. Cell. Probes. 1:141-149.

28. Takai, T., Ono, M., Hikida, M., Ohmori, H., and 
Ravetch, J.V. 1996. Augmented humoral and anaphylactic responses in Fc $\gamma$ RII-deficient mice. Nature. 379:346-349.

29. Ravetch, J.V., and Bolland, S. 2001. IgG Fc receptors. Annu. Rev. Immunol. 19:275-290.

30. Nieswandt, B., et al. 2003. Targeting of platelet integrin $\alpha_{\mathrm{II}} \beta_{3}$ determines systemic reaction and bleeding in murine thrombocytopenia regulated by activating and inhibitory Fc $\gamma$ R. Int. Immunol. 15:341-349.

31. Samuelsson, A., Towers, T.L., and Ravetch, J.V. 2001. Anti-inflammatory activity of IVIG mediated through the inhibitory Fc receptor. Science. 291:484-486.

32. Jordan, M.B., van Rooijen, N., Izui, S., Kappler, J., and Marrack, P. 2003. Liposomal clodronate as a novel agent for treating autoimmune hemolytic anemia in a mouse model. Blood. 101:594-601.

33. Takai, T. 2002. Roles of Fc receptors in autoimmunity. Nat. Rev. Immunol. 2:580-592.

34. Hillmen, P., et al. 2004. Effect of eculizumab on hemolysis and transfusion requirements in patients with paroxysmal nocturnal hemoglobinuria. N. Engl. J. Med. 350:552-559.

35. Young, N.S. 2005. Paroxysmal nocturnal hemoglobinuria: current issues in pathophysiology and treatment. Curr. Hematol. Rep. 4:103-109.

36. Hazenbos, W.L., et al. 1996. Impaired IgG-dependent anaphylaxis and Arthus reaction in FcyRIII (CD16) deficient mice. Immunity. 5:181-188.

37. Höpken, U.E., Lu, B., Gerard, N.P., and Gerard, C. 1997. Impaired inflammatory responses in the reverse Arthus reaction through genetic deletion of the C5a receptor. J. Exp. Med. 186:749-756.

38. Wessels, M.R., et al. 1995. Studies of group B streptococcal infection in mice deficient in complement component $\mathrm{C} 3$ or $\mathrm{C} 4$ demonstrate an essential role for complement in both innate and acquired immunity. Proc. Natl. Acad. Sci. U. S. A. 92:11490-11494.

39. Radeke, H.H., et al. 2002. Opposite regulation of type II and III receptors for immunoglobulin G in mouse glomerular mesangial cells and in the induction of anti-glomerular basement membrane (GBM) nephritis. J. Biol. Chem. 277:27535-27544.

40. Haviland, D.L., Haviland, J.C., Fleischer, D.T., and Wetsel, R.A. 1991. Structure of the murine fifth complement component (C5) gene. J. Biol. Chem. 266:11818-11825. 